\title{
The Impacts of Applying Metal(loid) Enriched Wood Ash to Soils on the Growth and Elemental Accumulation of Rice
}

\author{
Luke Beesley $^{1} \cdot$ Rupert Hough ${ }^{1} \cdot$ Claire M. Deacon $^{2} \cdot$ Gareth J. Norton ${ }^{2}[$
}

Received: 2 August 2017 / Revised: 8 February 2018 / Accepted: 28 February 2018 / Published online: 9 March 2018

(C) The Author(s) 2018. This article is an open access publication

\begin{abstract}
The mobility and uptake of phosphorus, manganese, arsenic, copper, zinc and several other heavy metal(loid)s to rice shoots and grains were measured under controlled irrigation [flooded and non-flooded] conditions in a pot experiment. Doses of $0.1-1 \%$ (w:w) of a metal(loid)-rich wood ash containing $\leq 13,000 \mathrm{mg} \mathrm{kg}^{-1}$ phosphorus, manganese, arsenic, copper and zinc were applied to a study soil to determine the impacts of the ash on rice grain quality and the fate of metal(loid)s. Pore water and rice shoots and grains were analysed for beneficial and toxic elements derived from the ash, and Food-chain exposure modelling was applied to the experimental data thereafter to predict risk of onward impacts to human health. Concentrations of phosphorus and manganese in pore water increased with ash addition, though this did not enhance grain phosphorus or manganese. Zinc mobility was largely reduced over the course of the experiment, but appeared unrelated to ash dose. Arsenic presented the greatest mobility in pore water of all measured metal(loid)s $\left(\sim 2500 \mu \mathrm{g} \mathrm{l}^{-1}\right)$, with shoot concentrations displaying clear dose and irrigation response. Although rice concentrations of arsenic in grain were the lowest of all measured metal(loid)s, risk-modelling of the data showed that even a $0.1 \%$ addition of the study ash to soil could expose a high rice consuming cohort to a vastly increased probability of deleterious health impacts. Whilst it is unlikely that contaminated ash would be knowingly applied to land, this study highlights that even singular applications of metal(loid) rich ash to agricultural soils could have negative effects on crops and forward impacts to human health. Other application scenarios, whereby lesser contaminated ashes are repeatedly applied to soils, warrant further work with regard to potential risks of accumulated metal(loid)s entering the food chain.
\end{abstract}

Keywords Arsenic $\cdot$ Zinc $\cdot$ Manganese $\cdot$ Rice $\cdot$ Grain $\cdot$ Health risk assessment

\section{Introduction}

Rice (Oryza sativa L.) is a dietary staple for 3.5 billion people globally, providing more than $20 \%$ of their daily calorific intake (Khush 2013). As world population increases, output of dietary staple crops, like rice, will also need to rise to meet demand. Increased crop production can result from two

Electronic supplementary material The online version of this article (https://doi.org/10.1007/s12403-018-0273-2) contains supplementary material, which is available to authorized users.

Gareth J. Norton

g.norton@abdn.ac.uk

1 The James Hutton Institute, Craigiebuckler, Aberdeen AB15 8QH, UK

2 School of Biological Sciences, University of Aberdeen, Cruickshank Building, St Machar Drive, Aberdeen AB24 3UU, UK scenarios: either intensification (producing more yield per unit area) or extensification (increasing the available land for crop production) (Gregory and Nortcliff 2013). Soils that are deemed less than ideal for crop production, referred to as marginal soils, due to limitations such as low fertility and poor drainage, may be modified in some way, for example by the addition of amendments to enhance their productivity.

Liming is traditionally used to increase the $\mathrm{pH}$ of soils, modifying their chemical, biological and physical properties (Edmeades and Ridley 2003), though it is increasingly regarded as non-sustainable due to the sourcing of lime from non-renewable outlets. Wood ash, the solid by-product of wood incineration, has several proven beneficial effects on soils, such as an increase in soil $\mathrm{pH}$ and added nutrient value (Bougnom et al. 2009, 2012; Klemedtsson et al. 2010; PérezCruzado et al. 2010; Arshad et al. 2012; Saarsalmi et al. 2012; Podmirseg et al. 2013). This has been shown, in some cases, to lead to improved crop productivity (Pérez-Cruzado 
et al. 2010; Bougnom et al. 2012; Materechera 2012; Moilanen et al. 2012; Saarsalmi et al. 2012). Wood ash can contain, amongst a range of macro-nutrients (i.e. phosphorus, potassium), a wide range of other elements depending on the source of the wood (i.e. arsenic, copper, chromium) (e.g. Mollon et al. 2016).

Approximately two-thirds of the world's population are deficient in one or more essential mineral elements (White and Broadley 2008). For a number of these essential elements, plants are a potential source for increased dietary intake, facilitated through a number of mechanisms, such as amending soil to increase the concentration of specific elements available for plant uptake. Studies have explored the impacts that fly ash (a product from coal combustion) has on rice production and grain quality, and have observed a range of impacts (Patra et al. 2012; Singh et al. 2016). Patra et al. (2012) demonstrated that an application of 200 $\mathrm{t} \mathrm{ha}^{-1}$ of fly ash increased rice grain yield by up to $40 \%$; however, there did appear to be an increase in grain arsenic concentration of 1.8 times on the fly ash amended soils compared to the control soils. Singh et al. (2016) observed that plants grown on fly ash amended soils produced lower biomass and had increased sterility, and that concentrations of cadmium, chromium, lead and arsenic increased in the grains of plants grown on fly ash amended soils, compared to the control soils; however, in this case, the fly ash made up $50 \%$ of the growing matrix. Mollon et al. (2016) conducted experiments using wood ash derived from mixed waste and virgin wood sources, with resultant high concentrations of heavy metal(loid)s. Such ashes thus have high concentrations of elements that are both beneficial to plants, e.g. zinc and copper (White and Broadley 2008), and toxic to plants and, if accumulated within the edible faction of the plant, could be toxic to humans (e.g. arsenic, Meharg et al. 2009).

Rice is commonly grown under flooded paddy conditions. Flooded soils present anaerobic conditions that can confound the predictability of metal(loid) behaviour. Additionally, rice cultivation approaches can include periods of both dry and flooded soil and the transition between aerobic (or partially aerobic) and anaerobic conditions further complicates predictability of metal(loid) behaviour. For example, arsenic, iron and manganese become more available to plants under anaerobic conditions compared to aerobic conditions (Xu et al. 2008; Norton et al. 2012, 2013; Rinklebe et al. 2016). This is in contrast to elements like cadmium, copper and strontium, whose mobility is reduced in oxygen limited soils (Rinklebe et al. 2016).

In this study, we have investigated the impact that amending soil with a wood ash with high concentrations of metal(loid)s has on (1) the mobility of the metal(loid)s from the ash when applied to soil; (2) the impact that this has on the growth of rice, and the accumulation of the metal(loid)s in the rice shoots and grains in the context of biofortification and accumulation of toxic elements. To understand how different management practices impact on these factors the experiment was (3) conducted under both flooded and nonflooded conditions. Finally, (4) the resulting experimental data were used to model the impacts that ash addition to soil could have on human health when rice was considered as a dietary intake source of arsenic.

\section{Methods}

\section{Greenhouse Experiment}

The rice cultivars used in this experiment were Dawn and Nortai. Dawn has been identified as an arsenic sensitive cultivar, while Nortai has been identified as an arsenic-tolerant cultivar (Dasgupta et al. 2004). Dawn has also been identified as straighthead sensitive, while Nortai is a straighthead tolerant cultivar (Wells and Gilmour 1977). The ash used in this experiment has previously been characterised by Mollon et al. (2016). The soil used in this experiment was a commercial top soil from Rolawn (Norton et al. 2013). Elemental properties of the ash and soils are given in Table 1.

Soil and ash were mechanically mixed using the end over end method resulting in soil containing $0.1,0.3$ and $1 \%(\mathrm{w} / \mathrm{w})$ ash. A total of 64 pots were set up on the 20 th November 2014 (as outlined in Supplementary Fig. S1). Half the pots were lined with a water tight plastic liner. Eight lined pots were filled with $800 \mathrm{~g}$ of soil with no ash added, or with ash at $0.1,0.3$, or $1 \%$ (i.e. a total of 32 lined pots). Eight non-lined pots were filled with $800 \mathrm{~g}$ of soil with no ash added, or with ash at $0.1,0.3$, or $1 \%$ (i.e. a total of 32 non-lined pots). The soils were then wetted to field capacity on the 5th December 2014. On the 19th December, $0.3 \mathrm{~g}$ ammonium nitrate was added to each pot (as a source of nitrogen). On the 5th January 2015, 4 of the lined and 4 of the non-lined pots of each soil ash treatment (i.e. 24 pots in total) were sown with 4 seeds of the rice cultivar Dawn and the remaining 24 pots with the rice cultivar Nortai. Additionally, a 5-cm Rhizon sampler was inserted into each pot at a $45^{\circ}$, with the collar just submerged below the soil. On the 5th February 2015 (31 days after sowing (DAS)), the rice plants were thinned to a single plant per pot. On the 13th February 2015 (39

Table 1 Elemental concentration of the soil and ash Source Reproduced with permission from Mollon et al. (2016)

\begin{tabular}{lrllll}
\hline $\begin{array}{l}\text { Phos- } \\
\text { phorus } \\
\left(\mathrm{mg} \mathrm{kg}^{-1}\right)\end{array}$ & $\begin{array}{l}\text { Man- } \\
\text { ganese } \\
\left(\mathrm{mg} \mathrm{kg}^{-1}\right)\end{array}$ & $\begin{array}{l}\text { Copper } \\
\left(\mathrm{mg} \mathrm{kg}^{-1}\right)\end{array}$ & $\begin{array}{l}\text { Zinc } \\
\left(\mathrm{mg} \mathrm{kg}^{-1}\right)\end{array}$ & $\begin{array}{l}\text { Arsenic } \\
\left(\mathrm{mg} \mathrm{kg}^{-1}\right)\end{array}$ \\
\hline Soil & 419 & 3710 & 7.5 & 27.7 & 3.5 \\
Ash & 12,230 & 3310 & 8790 & 4670 & 9260 \\
\hline
\end{tabular}


DAS), prior to flooding, the first pore water sample was taken. Once the first pore water sample had been collected, the lined pots for each soil treatment and cultivar combination were flooded to $5 \mathrm{~cm}$ above the soil surface; the flooded conditions for these plants were maintained at this water level for the remainder of the experiment. The remaining pots were kept under aerobic conditions during the duration of the experiment. A second nitrogen application was applied on the 19th February 2015 (45 DAS) using the same application rate of ammonium nitrate as previously. Further pore water samples were collected from each pot on the 16th March 2015 (70 DAS), 5th May 2015 (120 DAS) and 30th July 2015 (206 DAS). Plants were harvested on the 8th August 2015 (215 DAS). The shoots and the grain were separated and dried at $80^{\circ} \mathrm{C}$ for 3 days. Once dry, the mass of the grains and shoots was determined. Prior to chemical analyses the rice grains were de-husked.

\section{Pore Water Analyses}

Once the pore water samples were collected they were immediately acidified with concentrated nitric acid to give a final concentration of $1 \%$ nitric acid. Prior to elemental analyses, the pore water was diluted 1:50 (in 1\% nitric acid) for iron and manganese analyses, and 1:5 for all other elements. Elemental analyses were performed by inductively coupled plasma-mass spectrometry (ICP-MS, Agilent Technologies 7500). Standards with the appropriate ranges were made from $1000 \mathrm{mg} \mathrm{l}^{-1}$ ICP-MS grade multi-element stock solution. For quality control, blank samples were included, as well as water certified reference material (CRM, BCR 610). To monitor fluctuations in the sensitivity of the ICP-MS analysis, a $10 \mu \mathrm{g} \mathrm{l}^{-1}$ rhodium solution was used as a control.

\section{Rice Shoot and Grain Analyses}

Certified reference material (CRM) (Oriental basma tobacco leaves [INCT-OBTL-5]) and rice flour [NIST $1568 \mathrm{~b}]$ ) were used for quality control; blanks were also included. De-husked rice grain and shoots were milled to a fine powder. Shoot samples were weighed $(0.1 \mathrm{~g})$ into $50-\mathrm{ml}$ polyethylene centrifuge tubes. Grain samples were weighed $(0.2 \mathrm{~g})$ into $50-\mathrm{ml}$ polyethylene centrifuge tubes. Samples were digested with concentrated nitric acid (TraceSELECT; Fluka) and hydrogen peroxide (Analytical reagent grade; Fisher) as described in Sun et al. (2009). Total phosphorus, manganese, copper, zinc, iron and arsenic determination was performed by ICP-MS. To monitor fluctuations in the sensitivity of the ICP-MS analysis, a $10 \mu \mathrm{g} 1^{-1}$ rhodium solution was used as a control.

\section{Statistical Analysis}

For elemental concentrations in the pore water samples, statistical analysis was conducted on the second, third and fourth sampling point (the first was prior to the water treatments) using SPSS (IBM SPSS Statistics 24). A three-way ANOVA was conducted on the pore water elemental concentrations with water treatment, ash treatment and day of sampling as the explanatory variables; pot number was used as the repeated measure. For the plant element concentrations and plant mass traits a three-way ANOVA was conducted with water treatment, ash treatment and cultivar as the explanatory variables. For the three-way ANOVAs, the presence of interactions between the three explanatory variables was also determined. For correlation analysis, a Pearsons correlation was used.

\section{Arsenic Risk Assessment}

Exposure to potentially toxic elements in rice is of most relevance to rice-based cultures such as those found in South and South-East Asia. Here, especially in subsistence-level communities, individuals often consume around a kilogram of rice (raw) every day (Minh et al. 2012). Subsistence-level communities are also more likely to use waste products as agricultural amendments and therefore more likely to use biomass ash as part of agricultural production.

To estimate potential risks associated with consuming rice fertilised using the biomass ash described in this paper, data characterising a previously studied subsistence-level community in Vietnam was employed. Full details of this study can be found in Minh et al. (2012). Briefly, the study population was located in the Red River Delta in Bac Ninh province, close to the city of Hanoi. In 2007, a representative sub-set $(n=270)$ of the population were invited to be interviewed. A total of 262 participants provided a full response. These individuals ranged in age from 3 to 84 years; 125 were male, 137 female (full details of the study population can be found in Minh et al. 2012).

Interviewees answered questions for all members of their households. During the interviews, participants provided information on dietary habits (including daily rice consumption) as well as other information such as age, gender and bodyweight. This data set was used to provide a realistic population with higher than average rice consumption. For each individual in the population, exposure to arsenic was estimated from the measured concentrations of arsenic in rice grains reported in this study.

In this study, we were specifically interested in the risks associated with consuming rice grown in soils amended 
with biomass ash; therefore, only ingestion was taken into consideration. Data from the questionnaire described in Minh et al. (2012) were used to estimate individual-level arsenic exposure using an adaptation of the methodology described by Hough et al. (2004). For each study participant $(n=262)$, an individual-level average daily dose (ADDi; $\mathrm{mg} \mathrm{As} \mathrm{kg}^{-1} \mathrm{BW} \mathrm{d}^{-1}$ ) was estimated using the following equation (Eq. 1; USEPA 2000):

$\mathrm{ADD}_{i}=\frac{\mathrm{As}_{i} \cdot \mathrm{IR}_{i} \cdot \mathrm{EF}_{i} \cdot \mathrm{ED}_{i}}{\mathrm{BW}_{i} \cdot \mathrm{AT}_{i}}$,

where $\mathrm{As}_{\mathrm{i}}$ is the concentration $\left(\mathrm{mg} \mathrm{kg}^{-1}\right)$ of inorganic arsenic in each participant's rice and assumed to be a fraction of 0.8 of the mean concentration of arsenic measured in rice grains after $0,0.1$ and $0.3 \%$ ash treatments; $\mathrm{IR}_{\mathrm{i}}$ is the daily average consumption/ingestion $\left(g\right.$ person ${ }^{-1} \mathrm{~d}^{-1}$ ) of rice by the participant; $\mathrm{BW}_{\mathrm{i}}$ represents the body weight $(\mathrm{kg})$ of each participant; $\mathrm{EF}_{\mathrm{i}}$ is exposure frequency $\left(\mathrm{d} \mathrm{y}^{-1}\right) ; \mathrm{ED}_{\mathrm{i}}$ is exposure duration (equivalent to the lifetime of the participant (Bennett et al. 1999)); and $\mathrm{AT}_{\mathrm{i}}$ is the averaging exposure time $\left(\mathrm{d} \mathrm{y}^{-1}\right)$.

The potential risk of deleterious health effects was expressed for each study participant as the ratio (hazard quotient, HQ) of the $\mathrm{ADD}_{\mathrm{i}}$ (Eq. (1)) to a reference dose $\left(\mathrm{RfD}_{\mathrm{As}}, \mathrm{mg} \mathrm{As} \mathrm{kg}^{-1} \mathrm{~d}^{-1}\right)$; Eq. (2):

$\mathrm{HQ}_{i}=\frac{\mathrm{ADD}_{i}}{\mathrm{RfD}_{\mathrm{As}}}$,

where $\mathrm{RfD}_{\mathrm{As}}$ is an estimate of the daily exposure to arsenic for an individual in the human population (including sensitive subgroups) that is likely to be without an appreciable risk of deleterious effects during a life time. The USEPA has published a chronic reference dose (RfD, $\mathrm{mg} \mathrm{kg}^{-1} \mathrm{~d}^{-1}$ ) for inorganic arsenic of $0.0003 \mathrm{mg} \mathrm{kg}^{-1} \mathrm{~d}^{-1}$ based on a no-observed-adverse-effect-level (NOAEL) of $0.0008 \mathrm{mg} \mathrm{kg}^{-1} \mathrm{~d}^{-1}$ for dermal effects in a Taiwanese agricultural community exposed to arsenic in well water (Tseng 1977; Tseng et al. 1968). The RfD will be used in this study.

\section{Results}

\section{Metal(loid)s in Pore Water}

A summary of the statistical difference between treatments and time points for the pore water elemental concentration is given in Table 2. Statistical analysis was conducted on the pore water sampling points taken on 70, 120 and 206 DAS. The first sampling point (39 DAS) was taken prior to the soils undergoing manipulation of the irrigation regime; therefore, it was not used in the statistical analysis.

The sampling day significantly affected the pore water element concentrations of phosphorus $(P<0.001)$, manganese $(P<0.001)$, copper $(P<0.001)$ and zinc $(P<0.001)$ (Table 2, Fig. 1). The concentration of zinc in the pore water showed the greatest response to sampling day, (Fig. 1d) rapidly decreasing in the pore water from the initial sampling point. The concentration of phosphorus also showed a trend of decreasing in latter sampling time points (Fig. 1a). The effect of sampling day on the concentrations of manganese and copper was less obvious than zinc and phosphorus, and does not show a trend across all sampling time points (Fig. 1b, c).

The water treatment (flooded vs. non-flooded) significantly impacted the concentration of manganese $(P<0.001)$, arsenic $(P=0.013)$ and copper $(P=0.001)$ in the extracted pore water. The concentration of manganese increased from the flooded soils compared to the non-flooded soils in the second, third and fourth sampling points (the first time point is prior to flooding). Generally, for the fourth (last) sampling point the concentration of manganese in the pore water taken from the flooded soil decreased compared to the second and third time points from the same soils (Fig. 1b). The concentration of copper in the non-flooded soils was generally higher than other metal(loid)s in the flooded soils for the second and third sampling days (Fig. 1c).

The concentration of all elements (phosphorus $(P<0.001)$; manganese $(P<0.001)$; copper $(P<0.001)$; arsenic $(P<0.001))$ except zinc was significantly affected by the ash treatment. Both the concentration of pore water
Table 2 Statistical significance outputs ( $P$ value) for the analysis of pore water elemental concentrations

\begin{tabular}{llllll}
\hline Factor & \multicolumn{2}{l}{ Pore water element concentration } & & \\
\cline { 2 - 5 } & Phosphorus & Manganese & Copper & Zinc & Arsenic \\
\hline Day (D) & $<0.001$ & $<0.001$ & $<0.001$ & $<0.001$ & NS \\
Ash addition (A) & $<0.001$ & $<0.001$ & $<0.001$ & NS & $<0.001$ \\
Water treatment (W) & NS & $<0.001$ & 0.001 & NS & 0.013 \\
W $\times$ D & NS & $<0.001$ & 0.001 & NS & NS \\
W $\times$ A & 0.001 & $<0.001$ & 0.041 & NS & 0.014 \\
$\mathrm{D} \times \mathrm{A}$ & $\mathrm{NS}$ & $\mathrm{NS}$ & $\mathrm{NS}$ & $\mathrm{NS}$ & $<0.001$ \\
$\mathrm{~W} \times \mathrm{D} \times \mathrm{A}$ & $\mathrm{NS}$ & $<0.001$ & $<0.001$ & $\mathrm{NS}$ & $<0.001$ \\
\hline
\end{tabular}



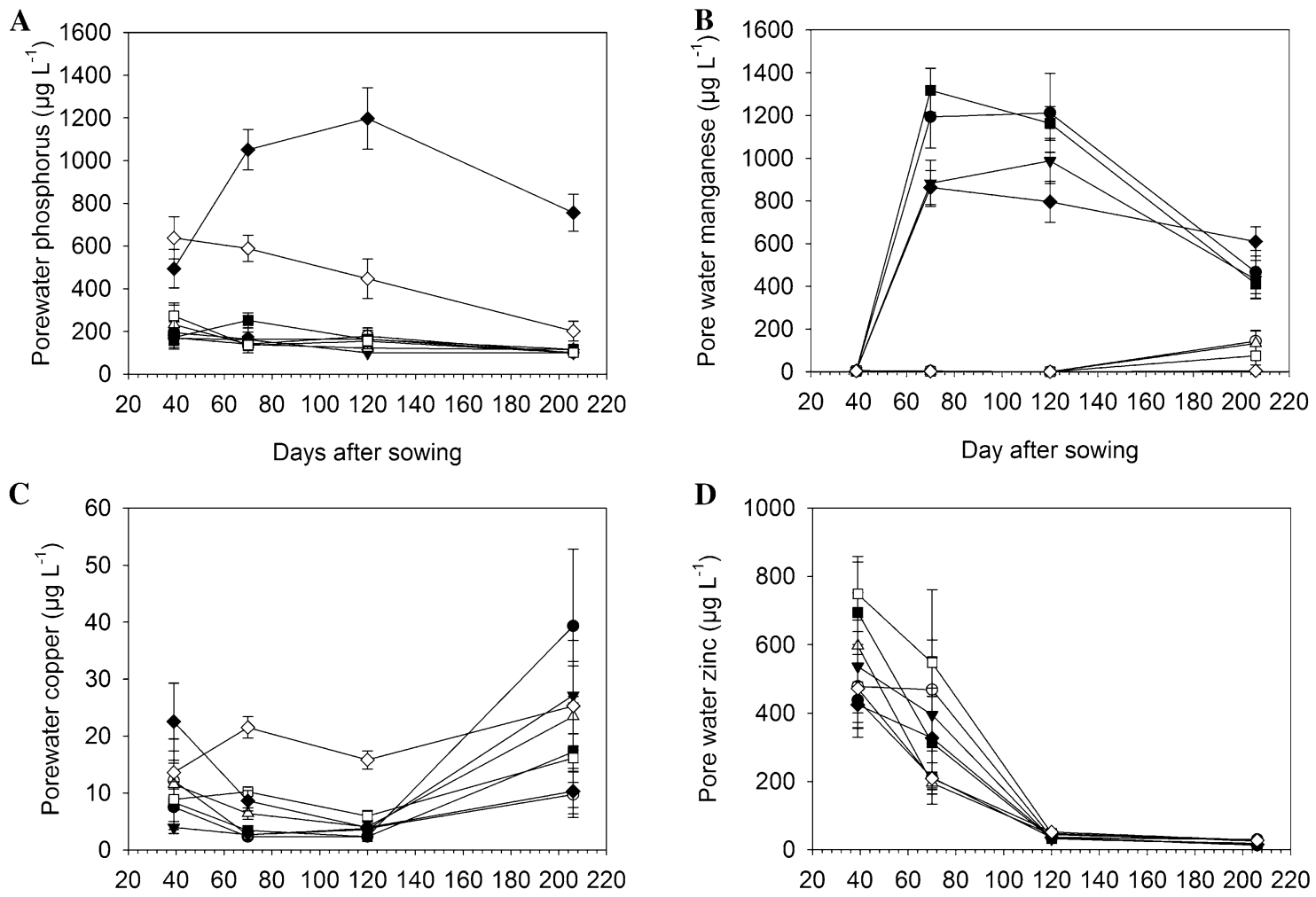

Day after sowing

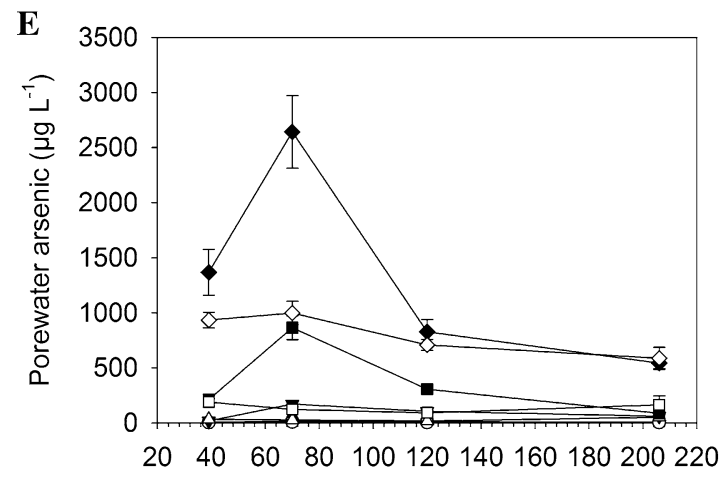

Day after sowing

Day after sowing

Fig. 1 Concentration of phosphorus (a), manganese (b), copper (c), zinc (d) and arsenic (e) in the pore water samples at the four different time points in the 8 different ash and water treatment combinations. Values presented are the mean and the standard error of the means $(n=8)$

arsenic and phosphorus increased with increasing addition of the ash (Fig. 1a, e). The effect of ash treatment on the concentrations of manganese and copper were less obvious and did not show a trend across all sampling time points (Fig. 1b, c).

In addition to the main effects of sampling day, water treatment and ash addition, a number of statistically significant two- and three-way interactions were observed for the pore water element concentrations (Table 2).

\section{Plant Mass Traits}

In the $1.0 \%$ ash treatment, the Dawn replicates grown under non-flooded conditions did not initiate flowering. Therefore, for these plants, only shoot element data are presented.

Shoot biomass was significantly affected by both water treatment $(P<0.001)$ and ash treatment $(P<0.001)$. Across both cultivars and all ash treatments the plants grown under flooded conditions produced, on average, a lower biomass 
(7.2 g) compared to those grown under non-flooded conditions $(10.0 \mathrm{~g})$. The $1.0 \%$ ash treatment caused a significant decrease in shoot biomass compared to the lower ash treatments, with plants grown on the control soil having a straw biomass of $10.4 \mathrm{~g}$ compared to $4.8 \mathrm{~g}$ in the $1 \%$ ash treatment. There was also a two-way interaction between the ash treatment and the cultivar $(P=0.009)$ as well as a three-way interaction between ash treatment, water treatment and cultivar $(P=0.001)$ (Table 3, Fig. 2).

Grain mass was significantly different between the cultivars across all treatments $(P<0.001)$, with Dawn on average producing a lower (2.1 g) grain mass than Nortai (3.3 g). Across both cultivars and water treatments, the ash treatment significantly impacted grain mass $(P<0.001)$, with the plants grown on the soils with the highest ash concentration having significantly lower grain mass (1.3 g) compared to the other three ash treatments (e.g. control $3.3 \mathrm{~g}$ ). As well as the impacts of cultivars and ash on grain mass, a three-way interaction between cultivar, ash treatment and

Table 3 Statistical output for the analysis of grain mass and shoot biomass

\begin{tabular}{lll}
\hline Factor & Plant mass & \\
\cline { 2 - 3 } & Shoot & Grain \\
\hline Water treatment (W) & $26.4^{* * *}(16.3 \%)$ & NS \\
Ash addition (A) & $24.0^{* * *}(36.5 \%)$ & $35.8^{* * *}(42.9 \%)$ \\
Cultivar (C) & $\mathrm{NS}$ & $50.6^{* * *}(21.8 \%)$ \\
$\mathrm{W} \times \mathrm{A}$ & $\mathrm{NS}$ & $\mathrm{NS}$ \\
$\mathrm{W} \times \mathrm{C}$ & $\mathrm{NS}$ & $\mathrm{NS}$ \\
$\mathrm{A} \times \mathrm{C}$ & $4.3^{* *}(6.4 \%)$ & $\mathrm{NS}$ \\
$\mathrm{W} \times \mathrm{A} \times \mathrm{C}$ & $6.5^{* *}(11.2 \%)$ & $10.4 * * *(12.7 \%)$ \\
\hline
\end{tabular}

Values reported are the $F$ values of the statistical analysis and values in brackets are the percentage of the overall variation explained by the variable

$N S$ not significant

$* P<0.05 ; * * P<0.01 ; * * * P<0.001$ water treatment significantly affected grain mass $(P<0.001)$ (Table 3, Fig. 2).

\section{Shoot Element Composition}

\section{Phosphorus}

The concentration of phosphorus in the shoots was significantly different between the 2 cultivars $(P=0.001)$. Mean concentrations of phosphorus across all ash treatments and both water treatments were 851 and $574 \mathrm{mg} \mathrm{kg}^{-1}$, for Dawn and Nortai, respectively (Fig. 3a). The ash treatment also significantly affected the shoot phosphorus concentration $(P=0.049)$, whilst there was a significant interaction between ash treatment and cultivar (Table 4 ).

\section{Manganese}

Manganese concentration in the shoots of the rice plants was significantly affected by flooding $(\mathrm{P}<0.001)$. Across all the ash treatments and both cultivars, the plants grown under flooded conditions had on average $40.5 \%$ more manganese than the plants grown under non-flooded conditions (mean flooded concentration $1167 \mathrm{mg} \mathrm{kg}^{-1}$ and non-flooded concentration $831 \mathrm{mg} \mathrm{kg}^{-1}$ ). The manganese concentration in the shoots of the rice plants was also significantly $(P<0.001)$ affected by the ash treatment (Table 4$)$. Across both water treatments and cultivars, the concentration of manganese in the plants was highest in those grown with no ash addition and significantly decreased with increasing ash addition; at $0 \%$ ash the average concentration of manganese was $1754 \mathrm{mg} \mathrm{kg}^{-1}$, at $0.1 \%$ ash it was $1295 \mathrm{mg} \mathrm{kg}^{-1}$, at $0.3 \%$ ash it was $747 \mathrm{mg} \mathrm{kg}^{-1}$, and at $1 \%$ ash it was $198 \mathrm{mg} \mathrm{kg}^{-1}$ (Fig. 3b).

\section{Copper}

The concentration of copper in the rice shoots was significantly different between the cultivars $(P=0.004)$. Mean
Fig. 2 Impact of ash and water treatment on a grain mass and b straw biomass for the 2 rice cultivars. Bars represent the mean and standard error of the mean $(n=4)$
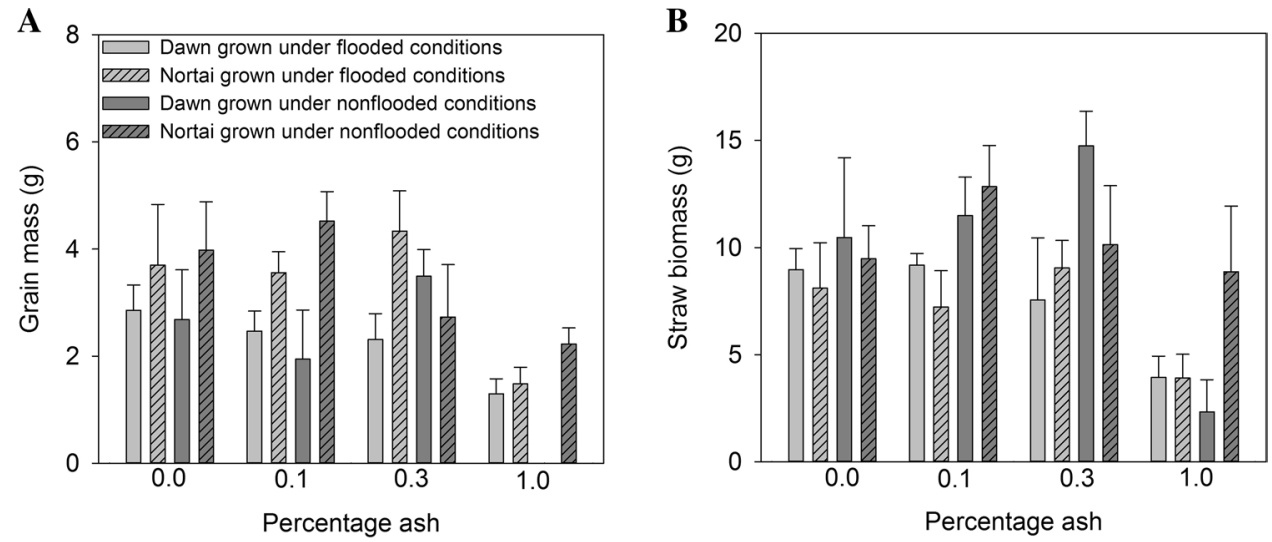

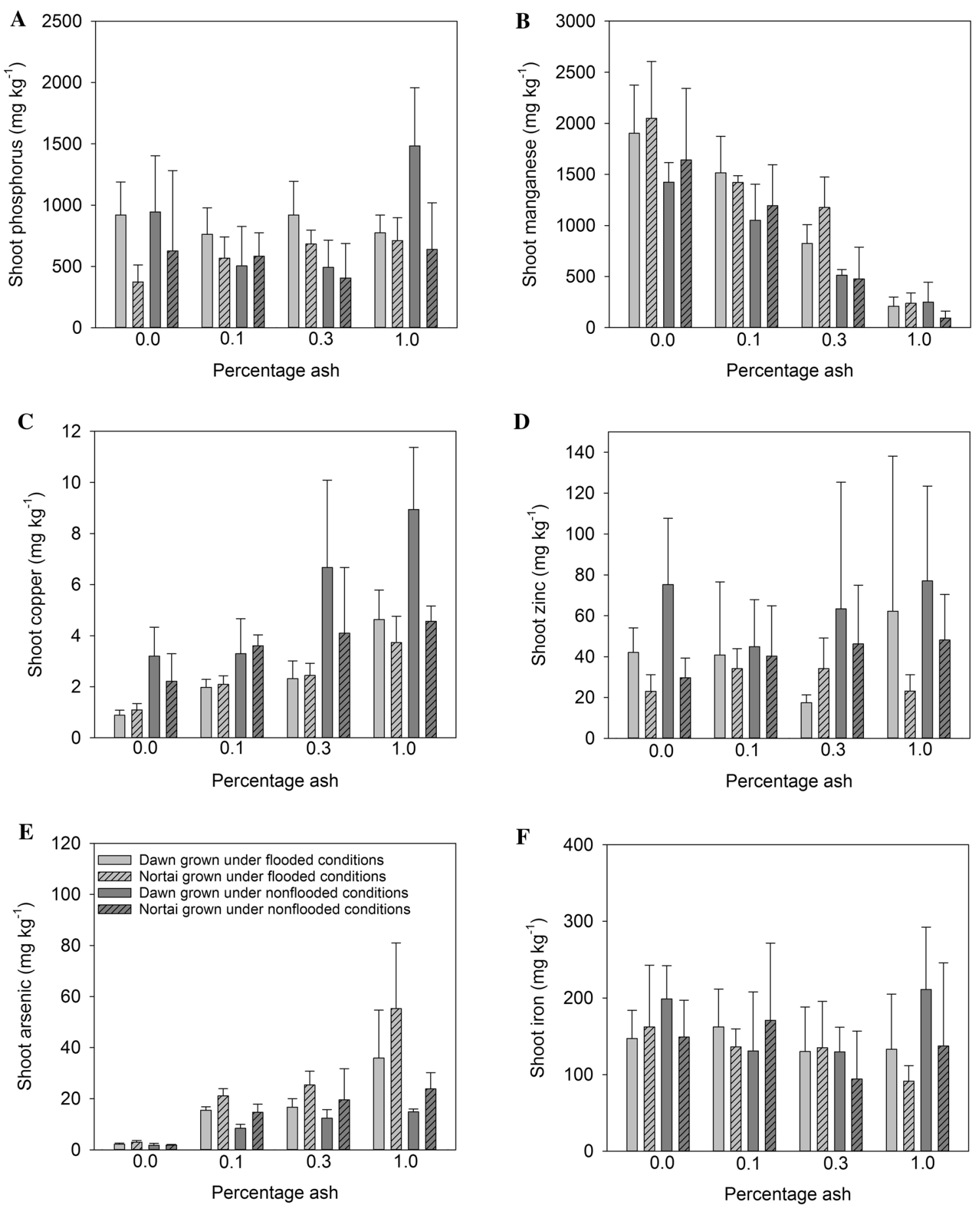

Fig. 3 Impact of ash and water treatment on shoot phosphorus (a), manganese (b), copper (c), zinc (d), arsenic (e) and iron (f) concentrations for the 2 rice cultivars. Bars represent the mean and standard error of the mean $(n=4)$

concentrations of copper across all treatments, were 3.99 and $2.98 \mathrm{mg} \mathrm{kg}^{-1}$, for Dawn and Nortai, respectively. The water treatment also significantly $(P<0.001)$ affected the concentration of copper in the rice shoots, with the plants grown under flooded conditions having significantly lower concentrations of copper $\left(2.40 \mathrm{mg} \mathrm{kg}^{-1}\right)$ compared to the plants grown under non-flooded conditions $\left(4.57 \mathrm{mg} \mathrm{kg}^{-1}\right)$. Additionally, the ash treatment significantly $(P<0.001)$ affected the concentration of copper in the rice shoots. Across both cultivars and water treatments, the highest copper concentration was measured in the shoots of plants grown with the $1.0 \%$ ash addition (mean $5.46 \mathrm{mg} \mathrm{kg}^{-1}$ ), while the lowest 
Table 4 Statistical output for the analysis of shoot elemental concentration

\begin{tabular}{|c|c|c|c|c|c|c|}
\hline \multirow[t]{2}{*}{ Factor } & \multicolumn{6}{|c|}{ Shoot element concentration } \\
\hline & Phosphorus & Manganese & Copper & Zinc & Arsenic & Iron \\
\hline Water treatment $(\mathrm{W})$ & NS & $12.3^{* * *}(5.0 \%)$ & $41.8 * * *(20.3 \%)$ & $5.3 *(7.3 \%)$ & $17.4 * * *(9.5 \%)$ & NS \\
\hline Ash addition (A) & $2.8 *(7.5 \%)$ & $61.2 * * *(73.8 \%)$ & $21.4 * * *(34.6 \%)$ & NS & $28.6 * * *(48.8 \%)$ & NS \\
\hline Cultivar (C) & $12.0 * *(13.7 \%)$ & NS & $9.0 * *(4.3 \%)$ & $5.0 *(7.6 \%)$ & $9.3 * *(4.7 \%)$ & NS \\
\hline $\mathrm{W} \times \mathrm{A}$ & $3.3 *(10.4 \%)$ & NS & NS & NS & $5.8 * *(9.2 \%)$ & NS \\
\hline $\mathrm{W} \times \mathrm{C}$ & NS & NS & $7.1 *(3.7 \%)$ & NS & NS & NS \\
\hline $\mathrm{A} \times \mathrm{C}$ & NS & NS & $3.4 *(5.7 \%)$ & NS & NS & NS \\
\hline $\mathrm{W} \times \mathrm{A} \times \mathrm{C}$ & NS & NS & NS & NS & NS & NS \\
\hline
\end{tabular}

Values reported are the $F$ values of the statistical analysis and values in brackets are the percentage of the overall variation explained by the variable

NS not significant

$* P<0.05 ; * * P<0.01 ; * * * P<0.001$

concentration was observed in the $0.0 \%$ ash treatment (mean $1.85 \mathrm{mg} \mathrm{kg}^{-1}$ ) (Fig. 3c). Significant interactions between water treatment and cultivar, and ash treatment and cultivar were also detected (Table 4).

\section{Zinc}

Zinc concentrations were significantly different between the two cultivars across all treatments $(P=0.03)$, with Dawn having the highest average concentration of shoot zinc (52.9 $\mathrm{mg} \mathrm{kg}^{-1}$ ) compared to Nortai $\left(34.9 \mathrm{mg} \mathrm{kg}^{-1}\right)$. The water treatment also significantly affected the concentration of zinc in the shoots $(P=0.026)$. Across all ash treatments, the plants grown in flooded soil had significantly lower zinc concentrations than those grown in the non-flooded conditions (34.6 mg kg-1 flooded; $53.1 \mathrm{mg} \mathrm{kg}^{-1}$ non-flooded) (Table 4, Fig. 3d),

\section{Arsenic}

The concentration of arsenic in the shoots was significantly $(P=0.004)$ different between the cultivars. Across all treatments, Nortai had a significantly higher shoot arsenic concentration than Dawn (mean Nortai shoot arsenic $20.6 \mathrm{mg} \mathrm{kg}^{-1}$ and mean Dawn shoot arsenic $13.5 \mathrm{mg} \mathrm{kg}^{-1}$ ). Concentrations of arsenic in shoots were also significantly affected by the water treatment $(P<0.001)$. Across all the ash treatments, on average, flooding reduced shoot arsenic by $44.3 \%$ compared to the plants grown under nonflooded conditions (mean shoot arsenic concentration in flooded plants was $21.9 \mathrm{mg} \mathrm{kg}^{-1}$ and in unflooded plants was $12.2 \mathrm{mg} \mathrm{kg}^{-1}$ ). Additionally, the concentration of arsenic in the shoots was significantly affected by the ash treatment. Across both water treatment and both cultivars, the highest average shoot arsenic concentration was observed in the $1.0 \%$ ash treatment $\left(32.5 \mathrm{mg} \mathrm{kg}^{-1}\right)$ and the lowest concentration in the $0.0 \%$ ash treatment $\left(2.2 \mathrm{mg} \mathrm{kg}^{-1}\right)$. The shoot arsenic concentration was also significantly affected by an interaction between the water treatment and ash treatment (Table 4, Fig. 3e).

Iron

Iron concentration in the shoots was not significantly different between the two cultivars, or affected by water treatment or ash treatment (Table 4, Fig. 3f).

\section{Grain Element Composition}

\section{Phosphorus}

The only factor that significantly affected the concentration of phosphorus in the grain was cultivar $(P<0.001$; Table 5). Across the water and ash treatments, the concentration of phosphorus in the grains of Dawn was $30.2 \%$ higher than Nortai (Dawn $3769 \mathrm{mg} \mathrm{kg}^{-1}$; Nortai $2894 \mathrm{mg} \mathrm{kg}^{-1}$ ) (Fig. 4a).

\section{Manganese}

Manganese concentrations in the rice grains were significantly affected by flooding $(P=0.001)$. Across all ash treatments and both cultivars, plants grown under flooded conditions have significantly lower grain manganese (40.4 $\mathrm{mg} \mathrm{kg}^{-1}$ ) compared to plants grown under non-flooded conditions (51.8 $\mathrm{mg} \mathrm{kg}^{-1}$ ). Manganese grain concentration was also significantly affected by the ash treatment $(P<0.001)$, with the plants grown with $0.0 \%$ ash having significantly higher grain manganese than the plants grown with ash in the soil (Fig. 4b). In addition to the individual significant impacts of water and ash treated, there was a 
Table 5 Statistical output for the analysis of grain elemental concentration

\begin{tabular}{|c|c|c|c|c|c|c|}
\hline \multirow[t]{2}{*}{ Factor } & \multicolumn{6}{|c|}{ Grain element concentration } \\
\hline & Phosphorus & Manganese & Copper & Zinc & Arsenic & Iron \\
\hline Water treatment $(\mathrm{W})$ & NS & $13.0 * *(15.7 \%)$ & $61.0 * * *(36.2 \%)$ & $5.8 *(2.6 \%)$ & NS & NS \\
\hline Ash addition (A) & NS & $10.3 * * *(23.0 \%)$ & $22.9 * * *(29.7 \%)$ & $47.5 *(5.5 \%)$ & $139.9 * * *(84.5 \%)$ & NS \\
\hline Cultivar (C) & $58.3 * * *(56.9 \%)$ & NS & $14.3 * *(7.3 \%)$ & $132.8 * * *(68.2 \%)$ & NS & NS \\
\hline $\mathrm{W} \times \mathrm{A}$ & NS & $6.1 * *(15.2 \%)$ & NS & NS & $3.5^{*}(2.0 \%)$ & NS \\
\hline $\mathrm{W} \times \mathrm{C}$ & NS & NS & NS & NS & NS & NS \\
\hline $\mathrm{A} \times \mathrm{C}$ & NS & NS & $5.1 *(5.8 \%)$ & $6.1 * *(6.2 \%)$ & NS & NS \\
\hline $\mathrm{W} \times \mathrm{A} \times \mathrm{C}$ & NS & NS & NS & NS & NS & NS \\
\hline
\end{tabular}

Values reported are the $F$ values of the statistical analysis and values in brackets are the percentage of the overall variation explained by the variable

$N S$ not significant

$* P<0.05 ; * * P<0.01 ; * * * P<0.001$

significant interaction between both these factors $(P=0.005$; Table 5).

\section{Copper}

The concentration of copper in the rice grain was significantly different between cultivars $(P=0.001)$. Mean concentrations of copper across all treatments were 3.98 and $4.55 \mathrm{mg} \mathrm{kg}^{-1}$, for Dawn and Nortai, respectively. Grain copper concentration was also significantly $(P<0.001)$ affected by water treatments, with the plants grown under nonflooded conditions having a higher concentration of copper in their grains compared to plants grown under flooded conditions (mean non-flooded $4.86 \mathrm{mg} \mathrm{kg}^{-1}$; mean flooded $3.67 \mathrm{mg} \mathrm{kg}^{-1}$ ). Additionally, the different ash treatments had a significant effect on grain copper; plants grown on the control ash-treated soil had significantly lower grain copper concentrations than those grown on the ash amended soils $(P<0.001$; Fig. 3c). There was also a significant interaction between the ash treatment and the cultivar on grain copper $(P=0.012$; Table 5, Fig. 4c).

\section{Zinc}

Zinc grain concentration was significantly $(P<0.001)$ different between the two cultivars across both treatments, with Dawn having a higher average concentration than Nortai (mean Dawn $34.4 \mathrm{mg} \mathrm{kg}^{-1}$; mean Nortai $22.8 \mathrm{mg} \mathrm{kg}^{-1}$ ). Grain zinc concentration was also significantly $(P=0.025)$ affected by the ash treatment across both water treatments and cultivars, with the plants grown on the soil that had an ash addition having a lower grain zinc concentration than those grown on the soil without ash. Additionally, plants grown under flooded conditions had significantly $(P=0.021)$ lower grain zinc than those grown under non-flooded conditions; however, this was only a small difference of $9 \%$
(Fig. 3d). In addition to the impact of cultivar, water and ash, there was a significant $(P=0.006)$ interaction between the ash treatment and cultivar on grain zinc concentration (Fig. 4d, Table 5).

\section{Arsenic}

The concentration of arsenic in the grain was significantly $(P<0.001)$ different for the plants grown on soils which contained ash and those that did not. Mean concentrations of arsenic across both cultivars and water treatments for the plants grown on soil without ash addition was $0.19 \mathrm{mg} \mathrm{kg}^{-1}$; this increases to $0.47 \mathrm{mg} \mathrm{kg}^{-1}$ for the plants grown on soil containing $0.1 \%$ ash (Fig. 3e). As well as the significant effect of the ash treatment, there was a significant $(P=0.041)$ interaction between the ash and water treatments (Fig. 4e, Table 5).

Iron

The concentration of iron in the rice grains was not impacted by any of the treatments (Fig. 4f; Table 5).

\section{Comparison of Element Concentration in the Shoots and Grains of the Rice Plants}

Relationships between the concentration of each element in the shoots and grains were compared (Supplementary Fig. S2). There was no correlation for phosphorus in the grain and shoot, zinc in the grain and shoot, and iron in the grain and shoot. However, there were significant $(P<0.05)$ positive correlations between the concentrations of manganese in the shoot and grain, copper in the shoot and grain, and arsenic in the shoot and grain $(r=0.670, r=0.560$, and $r=0.643$ respectively). 

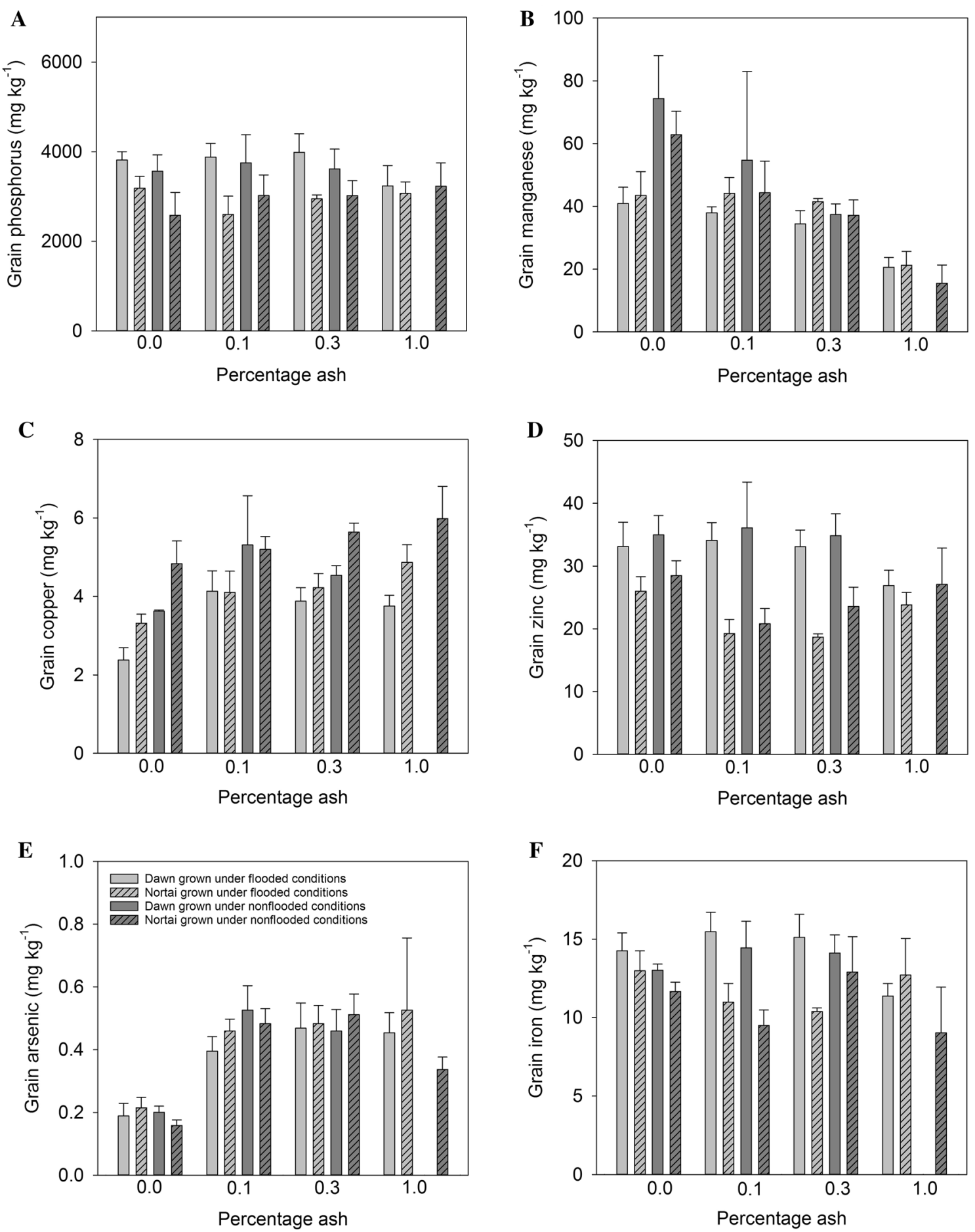

Fig. 4 Impact of ash and water treatment on grain phosphorus (a), manganese (b), copper (c), zinc (d), arsenic (e) and iron (f) concentrations for the 2 rice cultivars. Bars represent the mean and standard error of the mean $(n=4)$

\section{Arsenic Risk Assessment}

Based on risk assessment modelling, with no ash added to the study soil, the majority of individuals experienced a hazard quotient $(\mathrm{HQ})<1$ (men had a mean HQ of 0.7 , women
0.68 , children $(<13$ years old) 0.88$)$, suggesting that they will not experience deleterious health effects due to consuming arsenic in their rice (Fig. 5). However, even small levels of ash amendments increased these estimates of mean HQ significantly bringing them closer to 2.0 (Fig. 4), though 


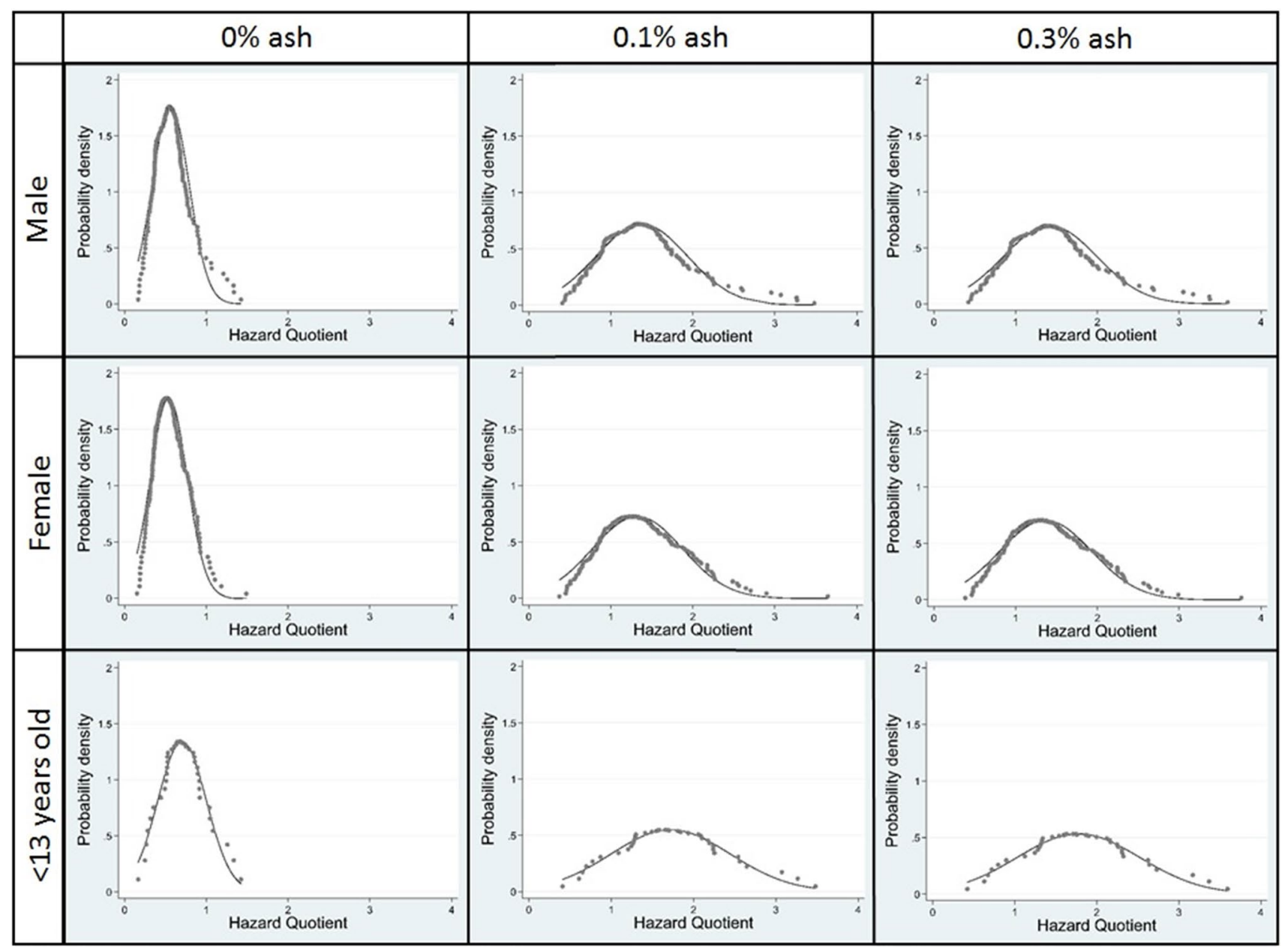

Fig. 5 Probability density functions (plotted as circles) of the Hazard Quotient (HQ, Eq. 2) for arsenic for adult males, females, and children consuming rice grown on soils amended with different levels $(0$,

there was no significant difference in values of HQ between 0.1 and $0.3 \%$ ash amendment.

\section{Discussion}

In previous studies, ash addition to soils has had a positive impact on plant growth (Pérez-Cruzado et al. 2010; Bougnom et al. 2012; Materechera 2012; Moilanen et al. 2012; Saarsalmi et al. 2012). However, in our study, increasing ash concentrations in the soil decreased overall plant performance; for example, at the $1.0 \%$ ash treatment, and under non-flooded conditions, the Dawn cultivars died.

\section{Ash Impacts on Phosphorus, Manganese and Iron}

Phosphorus concentrations in the pore water were significantly affected by ash addition (Fig. 1a), but the concentrations of phosphorus in the rice grains were not impacted
$0.1,0.3 \%$ ) of biomass ash. The solid line is the reference distribution (normal distribution)

(Fig. 4a). This indicates that, whilst the ash contained phosphorus which was mobile in the soil, this may not have been in a form that was readily available to the plants. It has been found that, of all the major nutrients in wood ash, phosphorus is the least bio-available (Demeyer et al. 2001); thus, the phosphorus in the wood ash was most likely present as weakly soluble aluminium phosphate or inaccessible as alumino-silicates (Ohno and Erich 1990; Erich 1991; Erich and Ohno 1992).

Manganese deficiency can occur in plants growing on organic soils, where the $\mathrm{Mn}^{2+}$ becomes bound to organic matter, or in calcareous soils, where the manganese is precipitated as manganese oxides. However, manganese toxicity has a greater impact on crop production than manganese deficiency (He et al. 2005). The flooded soil treatment in the present study mobilised high concentrations of manganese into the pore water compared to the non-flooded soils (Fig. 1b). However, this increased concentration of manganese in the pore water was not reflected in either 
the rice shoots or the grains (Figs. 3b, 4b). The addition of ash did not increase the concentration of manganese in the shoots and grain; on the contrary, it caused a decrease (Figs. 3b, 4b). Based on the concentration of manganese in the soil $\left(3710 \mathrm{mg} \mathrm{kg}^{-1}\right)$ and in the ash $\left(3300 \mathrm{mg} \mathrm{kg}^{-1}\right)$, it was expected that the addition of ash to the soil would have little effect on the total concentration of manganese in the soil. The observed decrease in manganese with increasing ash is probably due to the impact that the ash has on the soil $\mathrm{pH}$. In a previous study using this ash, it was observed that the $\mathrm{pH}$ increased sharply on the addition of the ash (Mollon et al. 2016) as observed by others (e.g. Bougnom et al. 2009; Ochecova et al. 2014), though this effect may be relatively short lived, as shown by Mollon et al. (2016) when leaching the ash with de-ionised water in a column test. Manganese is present in soils in a number of different oxidation states $(0$, II, III, IV, VI and VII) (Millaleo et al. 2010), with the most soluble form being $\mathrm{Mn}(\mathrm{II})$. The solubility of manganese is reduced as $\mathrm{pH}$ increases (Rengel 2000). At lower $\mathrm{pH}$, manganese in the soil is present as $\mathrm{Mn}^{2+}$ ions, which can be readily transported into roots cells (Marschner 1995), whereas at higher soil $\mathrm{pH}$ manganese is found in other forms, including $\mathrm{Mn}(\mathrm{III})$ and $\mathrm{Mn}(\mathrm{IV})$, which are not taken up by plants. As expected, flooding increased manganese in the soils solution (Fig. 1b), as negative redox favours manganese solubility (Rinklebe et al. 2016) where $\mathrm{Mn}^{4+}$ is reduced to $\mathrm{Mn}^{2+}$. However, this increase in manganese in the pore water was not mirrored in the plant tissue manganese concentrations, suggesting a more complex uptake of manganese by the plants from the soil solution. There was a strong relationship between the manganese in the shoots and the grains, with the plants that accumulated high manganese in the shoots also having high manganese in the grains.

While the concentration of iron was not determined in the pore water it was in the shoots and grains of the plants (Figs. 3f, 4f). The concentration of iron in both the shoots and the grains was not impacted by any experimental treatment, and was unchanged between cultivars. This could be related to the high degree of iron homeostasis in the plants.

\section{Behaviour of Copper and Zinc}

Copper is an essential micronutrient for plants (White and Greenwood 2013). The ash used in this study is rich in copper $8790 \mathrm{mg} \mathrm{kg}^{-1}$, and at a much higher concentration than the soil $\left(7.5 \mathrm{mg} \mathrm{kg}^{-1}\right)$, therefore the addition of ash increased the total copper in the soil, with the highest ash treatment having a copper concentration approximately 35 times higher than the soil. This resulted in an increase in concentration of copper in the pore water, rice shoots and grain (Figs. 1c, 3c, 4c). Copper in the grains was higher in plants that were grown under non-flooded conditions. This variation in copper concentration due to water treatment
(Fig. 4c) was probably due to the redox of the soil, as copper mobility has been observed to increase in aerobic soils (Rinklebe et al. 2016). Under reduced conditions, the available $\mathrm{Cu}^{2+}$ is reduced to less available $\mathrm{Cu}^{+}$(Rinklebe et al. 2016). Additionally, in anaerobic conditions, fewer copper colloids can be formed by microbes (Weber et al. 2009).

Like copper, zinc is an essential micronutrient for plants, involved in a wide range of physiological processes (White and Greenwood 2013), and is also a micronutrient that is essential for human health (White and Broadley 2008). Therefore zinc-rich ash could be an ideal zinc supplement for soils, if the zinc is in a bioavailable form. Total concentration of zinc was very high in the ash tested here compared to the soil (soil zinc $27.7 \mathrm{mg} \mathrm{kg}^{-1}$; ash zinc $4670 \mathrm{mg} \mathrm{kg}^{-1}$ ), therefore at the highest ash treatment (1.0\%) the total zinc in the amended soils was approximately $74.4 \mathrm{mg} \mathrm{kg}^{-1}$. However, the ash treatments did not significantly increase zinc in the pore water (Table 2). The greatest impact on zinc in the pore water was the sampling day, with the concentration in the pore water rapidly decreasing over the course of the experiment; this suggests that the labile/soluble zinc pool in this soil (regardless of ash treatment) was rapidly depleted. In the grain the largest impact on zinc was between the two cultivars, with Dawn accumulating more zinc than Nortai. These results for zinc in the plant tissue are similar to those observed by Mollon et al. (2016) using the same ash, albeit with ryegrass in that study.

\section{Arsenic in Pore Water and Rice}

The addition of ash to the soil greatly increased the concentration of arsenic in the pore water (Fig. 1e). This was expected as the total concentration of arsenic in the soil is $3.5 \mathrm{mg} \mathrm{kg}^{-1}$ compared to $9259 \mathrm{mg} \mathrm{kg}^{-1}$ in the ash, meaning that the highest ash (1.0\%)-treated soil would have an arsenic concentration of approximately $96 \mathrm{mg} \mathrm{kg}^{-1}$. This high soil arsenic concentration could be one of the factors that caused the plants to die in the highest ash treatment, as high arsenic concentrations have been linked to phytotoxicity (Meharg and Hartley-Whitaker 2002). Under flooded conditions, it would be expected that arsenic in the pore water would have increased (Xu et al. 2008) and this could have led to plants grown under flooded conditions accumulating an order of magnitude more arsenic (Xu et al. 2008; Norton et al. 2012, 2013). While there was a significant effect of flooding on pore water arsenic concentrations (Table 2) and a significant effect of flooding on shoot arsenic, with plants grown under flooded conditions having higher shoot arsenic concentrations compared to those grown under non-flooded conditions (Fig. 3e) this was not reflected in the grain arsenic concentration (Fig. 4e). 


\section{Implications for Risk Assessment}

The recent EU limit on inorganic arsenic in rice (brown rice) is $0.25 \mathrm{mg} \mathrm{kg}^{-1}$ (Council Directive 2015/1006/EC). In the present study, it was found that the total arsenic in the rice grain exceeded the limit of $0.25 \mathrm{mg} \mathrm{kg}^{-1}$ with the addition of $0.1 \%$ ash, while rice grown on the non-ash amended soils was below this. The EU limit is based on inorganic arsenic content rather than total arsenic content; as the proportion of inorganic arsenic was not measured in this study, it is not directly possible to conclude if the ash treatment causes the EU limit to be exceeded. However, based on the literature (Norton et al. 2009, 2012), if $80 \%$ of the total arsenic in rice grains in the present study is inorganic arsenic, then the grains obtained would be above the limit.

The health risk assessment highlights the importance of context when assessing potential risks associated with the use of wood ash as an agricultural soil amendment. For the assessment in our study, we specifically selected a highly exposed community (i.e. one that consumes large amounts of rice from a minimal number of sources, and where individuals have relatively low body weights) as a 'realistic worst case scenario'. This scenario highlights that even for the $0 \%$ ash treatment, a small proportion of the study population are experiencing intakes of arsenic that exceed the RfD, simply due to their hefty reliance on rice. Thus, rice cultivation in any arsenic contaminated soils would increase concentrations of arsenic in rice grains to a level that equates to a potential risk for nearly all members of the study population. It would therefore be expected that a study cohort with a lower consumption of rice would not be exposed to such a high risk. Another factor to consider is that the wood ash used in the present study is one amongst myriad of wood ashes increasingly generated from various sources, containing various proportions of metal(loid)s; for example, Solo-Gabriele et al. (2002) reported total arsenic concentrations in the very broad range of 730-100,000 mg $\mathrm{kg}^{-1}$ for wood ashes composed of various construction and demolition waste woods, and batches of woods variously treated with chromated copper arsenate (CCA). Thus input parameters of any risk assessment, such as that reported in the present study, would need to be adjusted to reflect the source material. Lastly, and when considering the use of metal(loid) contaminated soils for food cultivation, it is important to mention the risk of direct intake of arsenic via ingestion; in the context of the present study it is likely that, under flooded conditions, soil ingestion (via dust inhalation for example) would be vastly minimised. However, direct ingestion of wood ashes during application to soils could be another risk exposure pathway to consider by this mode of soil fertilisation.

\section{Conclusions}

This study highlights a number of issues precluding the use of metal(loid) enriched wood ashes in rice cultivation. Firstly, though wood ash application increased soluble phosphorus and manganese, metal(loid) phytotoxicity appears to have resulted in negative impacts to plant growth and mortality of rice plants at higher ash applications. Secondly, whilst the addition of ash to soils resulted in the increase of copper in rice grains, there was little impact on grain zinc, which would be a desirable element to supplement via soil amendment. Lastly there was a significant increase in rice grain arsenic after ash addition, resulting in a predicted increase in risk of human exposure of arsenic through rice consumption. While it is unlikely that wood ash enriched in toxic metal(oid)s would knowingly be applied to cultivated soil, this practise may be occurring on a localised scale where the provenance of wood ashes is not known, or where there is a lack of knowledge regarding the biogeochemistry of heavy metal(loid)s. Thus, the ash used in this study appears to induce more negative impacts on rice cultivation than positive impacts, and it may be assumed that similarly contaminated ashes would induce deleterious effects if applied in the same manner, whether in singular dosage or repeated applications.

Open Access This article is distributed under the terms of the Creative Commons Attribution 4.0 International License (http://creativeco mmons.org/licenses/by/4.0/), which permits unrestricted use, distribution, and reproduction in any medium, provided you give appropriate credit to the original author(s) and the source, provide a link to the Creative Commons license, and indicate if changes were made.

\section{References}

Arshad MA, Soon YK, Azooz RH, Lupwayi NZ, Chang SX (2012) Soil and crop response to wood ash and lime application in acidic soils. Agron J 104:715-721

Bennett DH, Kastenberg WE, McKone TE (1999) A multimedia, multiple pathway risk assessment of atrazine: the impact of age differentiated exposure including joint uncertainty and variability. Reliab Eng Syst Safe 63:185-198

Bougnom BP, Mair J, Etoa FX, Insam H (2009) Composts with wood ash addition: a risk or a chance for ameliorating acid tropical soils? Geoderma 153:402-407

Bougnom BP, Niederkofler C, Knapp BA, Stimpfl E, Insam H (2012) Residues from renewable energy production: their value for fertilizing pastures. Biomass Bioenerg 39:290-295

Council Directive 2015/1006/EC of 26 June 2015 on Amending Regulation (EC) No 1881/2006 as regards maximum levels of inorganic arsenic in foodstuffs

Dasgupta T, Hossain SA, Meharg AA, Price AH (2004) An arsenate tolerance gene on chromosome 6 of rice. New Phytol 163:45-49

Demeyer A, Voundi Nkana JC, Verloo MG (2001) Characteristics of wood ash and influence on soil properties and nutrient uptake: an overview. Bioresour Technol 77:287-295 
Edmeades DC, Ridley AM (2003) Using lime to ameliorate topsoil and subsoil acidity. In: Rengel Z (ed) Handbook of soil acidity. Marcel Dekker Inc., NewYork, pp 297-336

Erich MS (1991) Agronomic effectiveness of wood ash as a source of phosphorus and potassium. J Environ Qual 20:576-581

Erich MS, Ohno T (1992) Phosphorus availability to corn from wood ash amended soils. Water Air Soil Pollut 64:475-485

Gregory PJ, Nortcliff S (2013) The new challenge—sustainable production in a changing environment. In: Gregory PJ, Nortcliff S (eds) Soil conditions and plant growth. Blackwell, New York

He ZL, Yang XE, Stoffella PJ (2005) Trace elements in agroecosystems and impacts on the environment. J Trace Elem Med Biol 19:125-140

Hough RL, Breward N, Young SD, Crout NMJ, Tye AM, Moir AM, Thornton I (2004) Assessing potential risk of heavy metal exposure from consumption of home-produced vegetables by urban populations. Environ Health Persp 112:215-221

Khush GS (2013) Strategies for increasing the yield potential of cereals: case of rice as an example. Plant Breed 132:433-436

Klemedtsson L, Ernfors M, Björk RG, Weslien P, Rütting T, Crill P, Sikström U (2010) Reduction of greenhouse gas emissions by wood ash application to a Picea abies (L.) Karst. forest on a drained organic soil. Eur J Soil Sci 61:734-744

Marschner H (1995) Mineral nutrition of higher plants. Academic Press, San Diego

Materechera SA (2012) Using wood ash to ameliorate acidity and improve phosphorus availability in soils amended with partially decomposed cattle or chicken manure. Commun Soil Sci Plan 43:1773-1789

Meharg AA, Hartley-Whitaker J (2002) Arsenic uptake and metabolism in arsenic resistant and non-resistant plant species. New Phytol 154:29-43

Meharg AA, Williams PN, Adomako E, Lawgali YY, Deacon C, Villada A, Cambell RCJ, Sun G, Zhu YG, Feldmann J, Raab A, Zhao FJ, Islam R, Hossain S, Yanai J (2009) Geographical variation in total and inorganic arsenic content of polished (white) rice. Environ Sci Technol 43:1612-1617

Millaleo R, Reyes-Diaz M, Ivanov AG, Mora ML, Alberdi M (2010) Manganese as essential and toxic element for plants: transport, accumulation and resistance mechanisms. J Soil Sci Plant Nutr 10:470-481

Minh ND, Hough RL, Thuy LT, Nyberg Y, Mai LB, Vinh NC, Khai NM, Öborn I (2012) Assessing dietary exposure to cadmium in a metal recycling community in Vietnam: age and gender aspects. Sci Total Environ 416:164-171

Moilanen M, Hytönen J, Leppälä M (2012) Application of wood ash accelerates soil respiration and tree growth on drained peatland. Eur J Soil Sci 63:467-475

Mollon LC, Norton GJ, Trakal L, Moreno-Jimenez E, Elouali FZ, Hough RL, Beesley L (2016) Mobility and toxicity of heavy metal(loid)s arising from contaminated wood ash application to a pasture grassland soil. Environ Pol 218:419-427

Norton GJ, Islam MR, Deacon CM, Zhao FJ, Stroud JL, McGrath SP, Islam S, Jahiruddin M, Feldmann J, Price AH, Meharg AA (2009) Identification of low inorganic and total grain arsenic rice cultivars from Bangladesh. Environ Sci Technol 43:6070-6075

Norton GJ, Pinson SRM, Alexander J, Mckay S, Hansen H, Duan GL, Islam MR, Islam S, Stroud JL, Zhao FJ, McGrath SP, Zhu YG, Lahner B, Yakubova E, Guerinot ML, Tarpley L, Eizenga GC, Salt DE, Meharg AA, Price AH (2012) Variation in grain arsenic assessed in a diverse panel of rice (Oryza sativa) grown in multiple sites. New Phytol 193:650-664

Norton GJ, Adomako EE, Deacon CM, Carey AM, Price AH, Meharg AA (2013) Effect of organic matter amendment, arsenic amendment and water management regime on rice grain arsenic species. Environ Pol 177:38-47

Ochecova P, Tlustos P, Szakova J (2014) Wheat and soil response to wood fly ash application in contaminated soils. Agron J 106:995-1002

Ohno T, Erich MS (1990) Effect of wood ash application on soil pH and soil test nutrient levels. Agric Ecosyst Environ 32:223-239

Patra KC, Rautray TR, Nayak P (2012) Analysis of grains grown on flu ash treated soils. Appl Radiat Isotopes 70:1797-1802

Pérez-Cruzado C, Solla-Gullón F, Merino A, Rodriguez-Soalleiro R (2010) Analysis of growth and nutrition of a young Castanea $\times$ coudercii plantation after application of wood-bark ash. Eur J For Res 130:209-217

Podmirseg SM, Seewald MSA, Knapp BA, Bouzid O, Biderre-Petit C, Peyret P, Insam H (2013) Wood ash amendment to biogas reactors as an alternative to landfilling? A preliminary study on changes in process chemistry and biology. Waste Manag Res 31:829-842

Rengel Z (2000) Uptake and transport of manganese in plants. In: Sigel A, Sigel H (eds) Metal ions in biological systems. Marcel Dekker, New York

Rinklebe J, Shaheen SM, Kewei Y (2016) Release of As, Ba, Cd, Cu, $\mathrm{Pb}$, and $\mathrm{Sr}$ under pre-definite redox conditions in different rice paddy soils originating from the U.S.A. and Asia. Geoderma 270:21-32

Saarsalmi A, Smolander A, Kukkola M, Moilanen M, Saramäki J (2012) 30-Year effects of wood ash and nitrogen fertilization on soil chemical properties, soil microbial processes and stand growth in a Scots pine stand. For Ecol Manag 278:63-70

Singh PK, Tripathi P, Dwivedi S, Awasthi S, Shri M, Chakrabarty D, Tripathi RD (2016) Fly-ash augmented soil enhances heavy metal accumulation and phytotoxicity in rice (Oryza sativa L.); A concern for fly-ash amendments in agriculture sector. Plant Growth Regul 78:21-30

Solo-Gabriele HM, Townsend TG, Messick B, Calitu V (2002) Characteristics of chromated copper arsenate-treated wood ash. J Hazard Mater 89:213-232

Sun G, Williams PN, Zhu Y, Deacon C, Carey A, Raab A, Feldmann J, Meharg AA (2009) Survey of arsenic and its speciation in rice products such as breakfast cereals, rice crackers and Japanese rice condiments. Environ Int 35:473-475

Tseng WP (1977) Effects and dose-response relationships of skin cancer and Blackfoot disease with arsenic. Environ Health Persp 19:109-119

Tseng WP, Chu HM, How SW, Fong JM, Lin CS, Yen S (1968) Prevalence of skin cancer in an endemic area of chronic arsenicism in Taiwan. J Natl Cancer Inst 40:453-463

USEPA (United States Environmental Protection Agency) (2000) Handbook for non-cancer health effects evaluation. US Environmental Protection Agency Press, Washington, DC, p 2000

Weber FA, Voegelin A, Kaegi R, Kretzschmar R (2009) Contaminant mobilization by metallic copper and metal sulphide colloids in flooded soils. Nat Geosci 2:267-271

Wells BR, Gilmour JT (1977) Sterility in rice cultivars as influenced by MSMA rate and water management. Agron J 69:451-454

White PJ, Broadley MR (2008) Biofortification of crops with seven mineral elements often lacking in human diets-iron, zinc, copper, calcium, magnesium, selenium and iodine. New Phytol 182:49-84

White PJ, Greenwood DJ (2013) Properties and management of cationic elements for crop growth. In: Gregory PJ, Nortcliff S (eds) Soil conditions and plant growth. Blackwell, New York

Xu XY, McGrath SP, Meharg AA, Zhao FJ (2008) Growing rice aerobically markedly decreases arsenic accumulation. Environ Sci Technol 42:5574-5579 